\title{
Bitki Biyoteknolojisi'nde MikroRNA Tabanlı İnterferans Uygulamaları
}

\author{
Fatma AYDINOĞLU ${ }^{1 *}$, Gizem AKTUĞ ${ }^{1}$ \\ ${ }^{1}$ Gebze Teknik Üniversitesi, Temel Bilimler Fakültesi, Moleküler Biyoloji ve Genetik Bölümü, \\ Gebze/Kocaeli \\ *Sorumlu yazar: faydinoglu@gtu.edu.tr
}

\begin{abstract}
Öz
Bitki biyoteknolojisi, modern genetik mühendisliği araçlarını kullanarak bitkilerin istenilen karakterlerinin iyileştirilmesini amaçlar. Son yıllarda, protein kodlamayan küçük RNA'lardan olan mikroRNA (miRNA) genlerinin yer aldığı, doğal gen ifadesini düzenleyici mekanizma olan RNA interferans (RNAi), bitki geliştirilmesinde faydalı bir araç olarak önem kazanmıştır. miRNA'ların, hemen hemen bütün biyolojik ve metabolik işlevde anahtar düzenleyici role sahip oldukları ortaya konulmuştur. Hücresel yolakların miRNA tabanlı RNAi ile manipüle edilmesi ile bitki yapısının değiştirilmesi, abiyotik streslere toleransın ve biyotik streslere direncin geliştirilmesi, bitkilerin besin değerlerince zenginleştirilmesi, meyve ve sebzelerde raf ömrünün uzatılması ve sekonder metabolit üretiminin artırılması gibi daha pek çok bitki biyoteknolojisi alanında başarılı örneklerin varlığı, bu teknolojinin gelecek vaat eden bir araç olduğunu göstermektedir. Bu bağlamda, bu derleme, bitki miRNA genleri ve miRNA tabanlı RNAi teknolojisinin bitki iyileştirilmesinde uygulamalarına dair son gelişmeleri sunmayı amaçlamaktadır.
\end{abstract}

Anahtar Kelimeler: Bitki biyoteknolojisi, miRNA, RNAi, Bitki iyileştirme

\section{MicroRNA-Based Interference Applications in Plant Biotechnology}

\begin{abstract}
Plant biotechnology aims to improve desirable characters of plants by using modern genetic engineering tools. Recently, RNA interference (RNAi), which is a natural sequence-specific gene expression regulatory mechanism involving non-coding small RNAs like microRNA (miRNA), has gained importance as a beneficial tool for crop improvement. MiRNAs are identified as the key regulators in almost all biological and metabolic processes. Hereby, manipulating miRNA-based RNAi pathways offer a promising tool in the presence of successful applications on several fields of plant biotechnology, such as altering plant architecture, improving abiotic stress tolerance and biotic stress resistance, enrichment the nutritional value of plants, prolonging shelf life of fruits and vegetables, enhancing secondary metabolite production. This review aims to provide the latest updates on plant miRNAs and applications of miRNA-based RNAi technology for crop improvement.
\end{abstract}

Key Words: Plant biotechnology, miRNA, RNAi, Plant improvement

\section{Giriş}

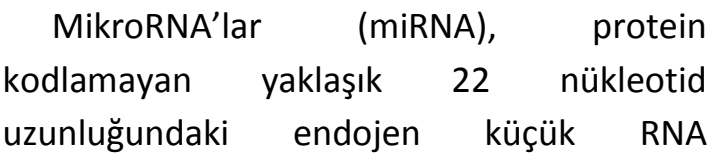

molekülleridir ve hedef mRNA'lara kısmen

kusursuz baz eşleşmesiyle bağlanıp mRNA degradasyonu veya translasyon inhibisyonu yoluyla gen ifadesini negatif olarak düzenlerler (Jones-Rhoades, 2012). İlk miRNA, Lee ve arkadaşları (1993) tarafından, Caenorhabditis elegans'ın gelişiminde rol alan ve lin-4 olarak adlandırılan 22 nükleotid uzunluğundaki bir küçük RNA'nın, LIN-14 
proteininin ifadesini lin-14 mRNA'sına kısmi baz eşleşmesi yaparak negatif olarak düzenlediğini gözlemledikleri çalışma ile keşfedilmiştir. Ancak, 2000'li yılların başında miRNA'ların diğer organizmalarda da keşfedilmesiyle, miRNA tabanlı transkripsiyonel düzenleme mekanizmasının gelişimsel süreçte genel ve önemli role sahip olduğu anlaşılmış ve son yıllarda bilim adamlarının, endüstrinin ve özel sektörün ilgi odağı haline gelmiştir. Günümüzde, gelişmiş biyoinformatik araçlar ve yeni nesil dizileme teknolojileri sayesinde yeni keşfedilen miRNA'ların sayısı önemli ölçüde artmıştır. En son çıkan miRNA veri bankasına (miRBase 21, June 2014) göre 223 türe ait 35828 olgun (mature) miRNA (ma-miRNA) bulunmaktadır (Kozomara ve Griffiths-Jones, 2014). Yine, aynı veri bankasında, 75 bitki türüne ait 8496 ma-miRNA yer almaktadır. Keşiflerinden bu yana yapılan pek çok araştırmada, miRNA'ların gelişimsel süreçlerin yanında, büyüme, abiyotik ve biyotik stres toleransı, biyokütle artışı gibi pek çok metabolik olayda rol oynadıkları gösterilmiştir (Sun, 2012).

MikroRNA'ların RNA interferans yolu ile spesifik dizi tabanlı gen susturma özelliği bitki biyoteknolojisi için alternatif bir yaklaşım sunmaktadır. Bu teknoloji, yüksek oranda faydalanabileceğimiz şekilde bitkilerin inşasına olanak vermektedir. Bu derlemede, kısaca miRNA'ların biyogenezi, evrimi ve işlevlerinden bahsedilip, miRNA tabanlı RNA interferansın (RNAi) bitki biyoteknolojisinde uygulamalarına dair örnekler sunulacak ve gelecekteki rolü tartışılacaktır.

miRNA'ların Biyogenezi, Evrimi ve Işlevleri

miRNA genleri, genomun intergenik bölgelerinde yer alırlar. Çoğu miRNA, kendi promotorundan RNA polimeraz II (Pol II) tarafından tek zincirli öncül yapı olarak transkripsiyona uğrar ve 5' 7-metilguanosin şapka ve 3' poliadenilat kuyruk takılarak kararlı hale getirilir. Bu primer miRNA (primiRNA), stem-loop yapısında katlanır ve oluşan hairpin benzeri ikincil yapı endonükleazlar tarafından kesilir (Rogers ve Chen, 2013). Hayvanlarda bu işlem, RNase III tipi bir enzim olan Drosha ile hairpin yapısının stem bölgesinden kesilmesiyle gerçekleşir. Oluşan öncül (precursor) miRNA (pre-miRNA) nükleustan sitoplazmaya Exportin 5 proteini tarafından taşınır. Bitkilerde ise, diğer bir RNase III olan DICERlike endonükleaz, çift zincirli hairpin RNA'yı kademeli olarak keserek önce pre-miRNA ve ardından $5^{\prime}$ fosfat ve $3^{\prime} 2$ nt asılı kalacak şekilde miRNA:miRNA*dupleksinin oluşumunu sağlar. Bu dupleksin $3^{\prime}$ ucundaki nükleotidler HEN1 tarafından metillenerek HASTY proteini yardımıyla sitoplazmaya taşınır. Burada dupleks açılarak olgun miRNA (ma-miRNA) RNA indüklenmiş gen susturma kompleksinin (RISC (RNA-induced silencing complex)) katalitik alt ünitesi olan AGO (Argonaute) proteinine katılarak hedef geni susturmak üzere hedef diziye yönlenmede öncü görevi görürken, miRNA* dizisinin hızlı bir şekilde degrade edildiği düşünülmektedir. Diğer taraftan, miRNA* dizisinin degrade edilmeyerek miRNA dizisi ile aynı şekilde fonksiyonel olarak aktif olduğuna dair kanıtlar da bulunmaktadır (Yang ve ark., 2011). Olgun miRNA'lar, hedef gene baz eşleşmesiyle bağlanarak mRNA degradasyonu veya translasyon inhibisyonu yoluyla transkripsiyon sonrası gen susturulmasında (PTGS) rol oynayarak gen ifadesini düzenlerler. Yapılan bazı çalışmalarda, gen susturulmasının yalnızca PTGS yoluyla değil aynı zamanda ilgili gen bölgelerinde DNA metilasyonu ile transkripsiyonel gen susturulmasında da (TGS) rol oynadıkları gösterilmiştir (Rogers ve 
Chen, 2013). Genel olarak, çift zincirli RNA'ların (dsRNAs) 21-23 nukleotidlik küçük RNA'lara ayrılması ve bu küçük RNA'ların hedef mRNA'ya bağlanarak mRNA degredasyonuna yol açtığı bu yüksek yapııı organizmalarda bulunan doğal mekanizma RNA interferans (RNAi) olarak adlandırılır.

Bitki miRNA'ları hayvanlarınkinin aksine, hedefledikleri dizilerle neredeyse birebir baz eşleşmesi gösterir ve tamamen hedefe özgündürler. $\mathrm{Bu}$ durum, bitki miRNA hedeflerini biyoinformatiksel olarak tanımlamaya olanak sağlar (Jones-Rhoades, 2012). Bitkilerde bazı miRNA ailelerinin ve hedef genlerinin türler arasında korunmuş olduğu deneysel ve hesaplamalı yöntemler sonucunda açığa çıkarılmıştır (Chavez Montes ve ark., 2014). Bu bağlamda yapılan araştırmada, 34 farklı bitki türünde, miRNA okuma sayısı sıklığı (reads per million (RPM)) arasındaki korelasyonu incelemiş ve RPM değeri yüksek miRNA'ların türlerin çoğunda korunduğunu, düşük RPM değerine sahip miRNA'ların ise türe özgü ve birbirlerinin substitüsyon varyantları olduklarını gözlenmiş̧ir. Fakat birçok miRNA yakın türler arasında korunmuş veya tamamen türe özgüdür. Arabidopsis thaliana ve Arabidopsis lyrata ile yapılan bir çalışma sonucunda birbirlerine yakın akraba türlerde bile miRNA'ların, beklenenin aksine, yüksek seviyede örtüşmedikleri görülmüştür (Fahlgren ve ark., 2010). Bu nedenle, genomda birçok miRNA lokuslarının yakın dönemde oluştukları ve bitki genomundaki bu lokusların dinamik bir şekilde evrimleşiyor olabileceği görüşü ortaya atılmıştır.

Yapılan çalışmalar, miRNA'ların yalnızca mRNA'ları değil aynı zamanda endojen olan uzun kodlamayan genler arası RNA'ları (Long intergenic noncoding RNAs (lincRNA) da hedeflediklerini göstermektedir (Jalali ve ark., 2013). Uzun kodlamayan RNA'lar
(IncRNA) yaklaşık 200 nükleotid uzunlukta kodlama dizisi (coding sequence (CDS)) ya da açık okuma çerçevesi (open reading frame (ORF)) içermeyen, gen ekspresyonlarını transkripsiyonel veya post-transkripsiyonel olarak düzenleyen transkriptlerdendir. LincRNA'ların, miRNA hedef genleri olan mRNA dizilerini içermeleri, lincRNA ve mRNA arasında bir rekabet oluşturarak mRNA degradasyonunu engellediği ve bu mekanizmanın miRNA'lar için bir çeşit tuzak oldukları hipotezini doğurmuştur (Fan ve ark., 2015).

Pek çok biyolojik sürecin düzenlenmesinde anahtar rol oynaması, miRNA'ların sentezinin ve degradasyonunun, yani homeostasisin sıkı bir şekilde kontrol edildiği mekanizmaların var olabileceği fikrini akla getirmiştir. Bu düşünceye yönelik yapılan az sayıdaki çalışmalarda, mekanizmaları tam olarak aydınlatılamamış olsa da birkaç miRNA degrade edici $3^{\prime}-5^{\prime}$ ve 5'-3' ekzoribonükleazlar (miRNases) tanımlanmış, Arabidopsis thaliana ve Chlamydomonas reinhardtii gibi model organizmalarda bazı örnekleri gösterilmiş, ancak herhangi bir endoribonükleaza henüz rastlanılmamıştır (Rogers ve Chen, 2013).

\section{Bitkilerde miRNA Tabanlı RNAi Uygulamaları} Bitki yapısının değiştirilmesi

Bitki boyu, gövde uzaması, yaprak ve çiçeklenme morfolojisi gibi bitkilerin yapısal özellikleri, fizyolojik ve biyokimyasal süreçleri, çevresel streslere dayanıklılık ve ürün verimi gibi tarımsal özellikleri doğrudan etkilediğinden yüzyıllardır ilgi odağı olmuştur. Son yıllarda, bitki yapısının değiştirilmesinde miRNA tabanlı RNAi mekanizmasından yararlanılmaya başlanmıştır. Bu çalışmalar sonucunda, bitki yapısını düzenleyen pek çok miRNA geni karakterize edilmiştir. Bu miRNA'ların, hücre 
farklılaşması, gelişimsel transisyon, hormon sinyali, yaprak, gövde ve kök büyümesi, organ polaritesi ve organların sınılarının belirlenmesi gibi büyüme ve gelişmeyle alakalı çok çeşitli süreçlerde rol oynadıkları (Sun, 2012) ve gelişimde kilit rol oynayan diğer trans-acting siRNA (tasi-RNA) ve phased-siRNA (phasi-RNA)'lerin üretilmelerinde de görev aldıkları gösterilmiştir (Allen ve ark., 2005).

Bitki yapısını etkileyen en önemli işlevlerden biri de gövdenin olgunlaşarak vejetatif fazdan çiçekle ilgili yapıların üretildiği reprodüktif faza geçiştir. $\mathrm{Bu}$ faz değişimi sırasında, miR156, miR157 ve miR172 genlerinin gövde ve çiçek gelişiminden sorumlu Squamosa Promoter Binding Protein-Like (SBPs/SPLs) adlı transkripsiyon faktörlerinin ifadesini düzenlediği ortaya konulmuştur (Poethig, 2013). Yine, miR172'nin, mısır (Zea mays L.) bitkisinin yaprağında genç evrenin sürdürülmesini sağlayan APETALA2 benzeri gen glossy15 (gl15)'i hedef alarak yetişkin evreye geçişi uyardığı saptanmıştır (Lauter ve ark., 2005). Pirinç (Oryza sativa) bitkisinde ise, Jiao ve arkadaşları (2010), OsSPL14 geninde meydana getirilen bir nokta mutasyonu ile OsmiR156- OsSPL14 regülasyonunu sekteye uğratarak, bitkinin kardeş sayısında azalış ve konaklama direncinde artışla birlikte ürün miktarında artış sağlamışlardır.

Yaprak ve kök sisteminin büyüklüğü, ışık ve besin alımını sınırlayarak bitki yapısını doğrudan etkiler. Son yıllarda, miRNA'ların yaprak ve kök gelişimi sırasında da rol aldıkları gösterilmeye başlanmıştır. Örneğin, miR390'ın mısır bitkisinde TAS3 ta-siRNA biyogenezini tetikleyerek yaprak polaritesinde görev aldığı gösterilmiştir (Nogueira ve ark., 2009). Yine aynı çalışmada, TAS3 ta-siRNA'nın yaprağın adaksiyal belirteçlerini kısıtlayarak abaksiyal bölgesinin sınırlarını belirleyen miR166'yı düzenleyici etkisi olduğu belirtilmiştir. Diğer bir çalışmada ile, erken ve geç yaprak senesens özelliği olan farklı iki mısır çeşidinde karşılaştırmalı RNA dizileme analizi sonucu 16 miRNA'nın ifadesinde farklılıklar saptanmış ve degradom dizileme sonucunda bu 16 miRNA'nın yaprak senesensini düzenleyen transkripsiyon faktörlerini hedefledikleri ortaya konulmuştur ( $\mathrm{Wu}$ ve ark., 2016). Kök gelişimi sırasında ise, miR167'nin, Arabidopsis thaliana'da oksin yanıt faktörünü (ARF) hedefleyerek bitkide olağan dışı bölgelerden kök oluşumunu düzenlediği (Gutierrez ve ark., 2009) ve miR164'ün NAC1 transkripsiyon faktörünü hedefleyerek yanal kök oluşumunu inhibe ettiği gösterilmiştir (Guo ve ark., 2005).

\section{Abiyotik streslere toleranslı bitkilerin geliştirilmesi}

Kuraklık, tuzluluk, sel, değişen sıcaklıklar ve besin eksikliği gibi abiyotik stresler, bitki büyümesini sınırlandırarak ürün verimini olumsuz yönde etkiler. Yapılan çalışmalar, bitkilerin uygun olmayan çevresel koşullar altında stres tolerans mekanizması geliştirerek hayatta kalabildiklerini göstermiştir. Ancak, stres toleransı pek çok genin iştirakiyle sağlandığından günümüzde abiyotik streslere dayanıklı bitki geliştirme çalışmaları yeterince başarı sağlayamamıştır (Shriram ve ark., 2016). Son yıllarda, miRNA genlerinin bitkinin stres toleransı geliştirme ve adaptasyon mekanizmaları sırasında düzenleyici rol oynadıklarına dair deliller hızla birikmeye başlamıştır (Shriram ve ark., 2016). Bu gelişmeler, miRNA genlerinin pek çok genin ifadesini düzenlemede rol alan transkripsiyon faktörlerini hedef aldıklarından, ilerleyen yıllarda miRNA tabanlı RNAi teknolojisi ile abiyotik streslere 
dayanıkı bitkilerin eldesi için umut vaat etmektedir. Bu doğrultuda, miR169'un, nuclear factor $Y$ A5 (NFYA5) transkripsiyon faktörünün ifadesini düzenleyerek bitki gelişiminde ve stres yanıtında önemli rol oynadığı saptanmıştır. Örneğin, mısır bitkisinde zma-miR169 ifadesinin, kuraklık (ABA ve PEG uygulaması ile) sırasında azalan, tuzluluk ( $\mathrm{NaCl}$ uygulaması) sırasında önce artan sonra azalan bir profil sergilediği gözlenmiştir (Luan ve ark., 2015). Pirinç bitkisinde ise, miR319'un, TEOSINTE BRANCHED/CYCLOIDEA/PCF

transkripsiyon faktörünü hedef alarak üşüme toleransında rol oynadığı gösterilmiştir (Yang ve ark., 2013).

Kuraklığın aksine fazla sulama da toprak boşluklarının suyla dolması nedeniyle köklerin oksijen alımını sınırlayarak bitkinin büyümesini olumsuz etkiler. Bu konuda, Zhai ve arkadaşlarının (2013) mısır bitkisinde yaptıkları araştırmada, miR167, miR393 ve miR172 genlerinin su stresi koşullarında taç köklerin gelişimini düzenlediği ortaya konulmuştur.

Domates bitkisinde yapılan bir çalışmada, stres yanıtını aktive eden bir sinyal molekülü olan abisisik asit (ABA) muamelesi sonucu, abiyotik stres adaptasyonu ve hastalık direnci sağlayan genleri hedef alan miRNA'ların ifadelerinin azaldığı saptanmıştır (Cheng ve ark., 2016). Bu sonuçlar, dışarıdan ABA muamelesi ile miRNA aracılıklı stres cevabının düzenlenebileceğini göstermektedir.

Besin eksikliği bir diğer önemli bitki büyüme sınırlayıcısıdır. Makro besin elementi olan fosfor, bitkilerde büyüme ve gelişmede rol alan biyokimyasal reaksiyonlar için elzemdir. Düşük fosfor konsantrasyonunda yetiştirilen mısır filizlerinin kök ve yapraklarında yapılan bir çalışmada, derinleme dizileme tekniği kullanılarak 8 'i yaprak, 7'si köke özgü olmak üzere 28 miRNA tanımlanmış ve bu miRNA'ların hedef genlerin çoğunlukla gelişiminde etkili olan transkripsyon faktörleri olduğu belirtilmiştir (Nie ve ark., 2016). Buna ilaveten, miRNA'ların nitrat eksikliğine bağlı olarak ifade oldukları da gösterilmiştir (Xu ve ark., 2011).

Biyotik streslere dirençli bitkiler geliştirilmesi

Böcekler, nematodlar, parazitik otlar, bakteriyel, fungal ve viral hastalıklar gibi biyotik etkenler bitkilerde strese yol açarak ürün verimini etkilemektedirler. Özellikle virüsler, en çok ürün kaybına sebep olan biyotik etkenlerdir. Günümüzde, hastalık direnci bitkilere biyoteknolojik yöntemlerle başarılı bir şekilde aktarılabilmiştir. Örneğin, RNAi teknolojisi kullanılarak bitki virüs etkileşimine dahil olan virütik yardımcı bileşen proteinazın (HCpro) sense ve antisense transkriptleri kullanılarak patetes $Y$ virüsüne karşı dirençli bitkiler elde edilmiştir (Waterhouse ve ark., 1998). Yine, farklı bitki türlerinde yapılan çalışmalarda, her bir biyotik stres koşuluna yanıt olarak ifade olan farklı miRNA'lar keşfedilmeye başlanmıştır. Pirinçte yapılan bir çalışmada ise, RRSV (rice ragged stunt virus) enfeksiyonu sırasında miR319'un biriktiği ve bu miRNA geninin hedefi olan TCP (TEOSINTE BRANCHED/CYCLOIDEA/PCF) transkripsiyon faktörünün baskılanması ile konak bitkinin hastalık fenotipi sergilediği gözlenmiştir. Sonuç olarak, miR319 birikiminin jasmonik asit (JA) seviyesinde azalmaya sebep olarak JA aracılı savunma mekanizmasını engellediği, enfeksiyonu kolaylaştırdığı saptanmıştır (Zhang ve ark., 2016). Örnekte görüldüğü gibi, miR319 geninin RNAi ile susturulmasıyla hastalık direncine sahip bitkiler elde etmek mümkün olabilir. 
Mısır bitkisinde ürün kaybına yol açan mısır cücelik hastalı̆̆ı (Maize rough dwarf disease), RBSDV (Rice black-streaked dwarf virus) virüsünün sebep olduğu bir hastalıktır. $\mathrm{Bu}$ virüse yanıt olarak düzenlenen miRNA yolaklarını açığa çıkarma amaçlı yapılan bir çalışmada, 17 miRNA ailesine ait 28 korunmuş miRNA, 3 korunmamış ve 14 yeni miRNA'nın ifadelerinde virüse yanıt olarak değişimler saptanmıştır ve hedef genleri belirlenerek enfeksiyon cevabını oluşturan yolak aydınlatılmaya çalışımıştır (Zhou ve ark., 2016). Sonuç olarak, miR169i-p5 ve miR8155'in, nucleolini ve NAD(P)-binding Rossmann-fold superfamily proteini negatif olarak düzenleyerek hastalık cevabında rol aldıkları tespit edilmiştir. Mısır bitkisinde hasat kaybına neden olan bir başka hastalık da Exserohilum turcicum (Pass.) mantarının sebep olduğu Kuzey Yaprak Yanıklığı hastalığıdır. E. turcicum ile aşılanan bitkilerde, bitki miRNA mikroarray tekniği ile, miR811, miR829, miR845 ve miR408 olmak üzere dört miRNA'nın ifadesinde enfeksiyona bağlı farklılık saptanmıştır (Wu ve ark.,. 2014). Bu miRNA genlerinin tahmini hedeflerinin ise metabolik, morfolojik ve fizyolojik adaptasyonunu düzenlediği belirtilmiştir.

\section{Bitkilerden alerjenlerin çıkartılması}

Fistık, elma gibi bazı yiyecekler tüketildiklerinde sahip oldukları alerjenler sebebiyle insanda alerjiye sebep olmaktadır. Yiyecek alerjisi, normal şartlarda zararsız olan bileşenlere karşı immunoglobulin E (IgE) mekanizması aracılığı ile aşırı duyarlııık gösterilmesi ile hayati tehlike yaratabilmektedir. Alerjik reaksiyonların tamamen iyileştirilerek kişinin yiyeceğe karşı gösterdiği duyarlılığı kökten ortadan kaldıracak bir tedavinin bulunmaması, yiyeceklerden alerjenlerin RNAi teknolojisiyle çıkarılması fikrini doğurmuştur. Bu amaç için, alerjeni üreten gene özgü miRNA'ların yüksek miktarda ifade ettirilmesi ya da yapay miRNA'ların (amiRNA) bitkiye aktarılması sonucu RNAi mekanizması tetiklenerek genin susturulması hedeflenmektedir. Bu doğrultuda, domateste Lyc e 1.01 ve Lyc e 1.02 genlerinin ürünü olan profilin (Le ve ark, 2006), soya fasülyesinde bulunan Gly $\mathrm{m} \mathrm{Bd}$ $30 \mathrm{~K}$ (Herman ve ark., 2003) ve elmadaki Mal d 1 (Gilissen ve ark., 2005) alerjenlerinin RNAi tekniği ile büyük oranda çıkartılması mümkün olmuştur.

\section{Erkek-kısır bitkilerin geliştirilmesi}

Anter sterilitesi veya sitoplazmik sterilite

Sitoplazmik erkek kısırlığı (CMS), bitkilerin canlı polen üretememesi durumudur ve maternal olarak kalıtıldığı düşünülmektedir. CMS, ürün verimini olumsuz etkilemesine rağmen, melezleme ve transgenik bitki polenlerinin yabani bitkiler ile tozlaşmasını önleme gibi çalışmalarda faydalı bir metod olarak kullanılmaktadır. CMS mekanizmasının aydınlatılması, yüksek ürün verimi elde edebilmek için önemlidir. Bununla ilgili olarak, miRNA'ların polen ve anter gelişimini de kapsayan birçok gelişimsel süreci düzenlediği bilgisinden yola çıkılarak yapılan bir araştırmada sekiz miRNA ailesiyle çalışılmış ve CMS anterlerdeki miRNA'ların ifadelerinde, verimli anterlere göre farklılık saptanmıştır. Bu miRNA'lara ait, hücre yapısı, stres yanıtı, gen ifadesini düzenleyen transkripsiyon faktörleri ve metabolik ve sinyal yolakları ile alakalı 18 geni hedef aldıkları belirlenmiş ve bu genlerin mikrospor gelişiminde önemli olduğu belirtilmiştir (Shen ve ark., 2011). Diğer bir çalışmada ise, mısır püskülünde miRNA biyogenezi için gerekli olan enzimi kodlayan dicer-like 1 geni, mutasyona uğratıldığında miRNA miktarındaki azalmaya bağı olarak stamen 
gelişiminde ve anterlerde nişasta birikiminde bozukluklar ve erkek kısırlığı gözlenmiştir (Field ve Thompson, 2016). Tütün ( $N$. tabacum cv. Samsun) bitkisinde de, yapılan bir çalışmada, mikrospor gelişimi esnasında ifade olan antere özgü TA29 geninin, RNAi teknolojisi kullanılarak ifadesi azaltılmıştır ve erkek kısır hatlar elde edilmiştir (Nawaz-ulRehman ve ark., 2007).

\section{Sekonder metabolit mühendisliği}

Bitki sekonder metabolitleri, ilaçların, kokuların, renk verici maddelerin, yiyecek katkı maddelerinin ve pestisitlerin kaynaklarıdır. Sekonder metabolit sentezi, çeşitli ara bileşiğin katıldığı birçok aşamada gerçekleşir. Bu aşamalarda görevli genlerin RNAi ile kontrol edilmesi ile istenilen miktarda metabolit elde edilebilmektedir. Bu amaç doğrultusunda, Papaver somniferum bitkisinde, morfinin biyosentetik enzimi olan salutaridinol 7-O-asetiltransferazı (SalAT) kodlayan genin transkript seviyesinin azaltıldığında, transgenik bitkilerde ara ürünler olan salutaridin ve salutaridinol biriktiği gözlenmiştir (Kempe ve ark., 2009). Yine, Panax ginseng bitkisinde dammarenediol sentaz (DDS) geninin ifadesinin baskılanması sonucu, transgenik bitkilerin köklerinde ginsenosit birikimi (\%85.4) gözlenmiş ve ginsenosit biyosentezinde DDS'nin önemli rol oynadığı belirtilmiştir (Han ve ark., 2006). Diğer bir çalışmada ise, Artemisia annua'dan sıtmaya karşı düşük miktarlarda izole edilebilen artemisinin ilacının, RNAi ile daha fazla miktarlarda elde edilmesi amaçlanmıştır. Sonuç olarak, Agrobacterium tumefaciens aracilı transformasyon ile elde edilen transgenik bitkilerde artemisinin biyosentezi ile yarışmalı yolak olan sterol yolağının önemli enzimi olan skualen sentazın (SQS) ifadesi baskılandığında artemisin miktarı artırılabilmiştir (Zhang ve ark., 2009).

\section{Çiçek rengi ve kokusunun modülasyonu}

Çiçek rengi ve kokusu, çiçekçilikte ekonomik ve estetik değerinden dolayı oldukça önemli özelliklerdir ve geleneksel Islah ve bitki biyoteknolojisinin yoğun ilgi alanıdır. Çiçek rengi, flavonoid pigmentleri ve antosiyanin sentezi ile meydana gelir. Polen taşıyıcıları çekmek için üretilen flavonoidler aynı zamanda bitkiyi ve üreme organlarını olası UV zararlarından, zararlı böceklerden ve patojenlerden korur (Gronquist ve ark., 2001). Antosiyanin biyosentezinde rol alan bazı yapısal genlerin RNAi ile baskılanarak antosiyanin birikiminin engellenmesi sonucu transgenik bitkilerde bitki renginin değiştiği çalışmalar yapılmıştır. Torenia hybrida bitkisinde yapılan bir çalışmada, antosiyanin ve flavonoid biyosentezinde önemli bir enzim olan kalkon sentaz (CHS), mRNA'sının 3'UTR bölgesi RNAi ile hedeflenip baskılanarak normal renginden daha açık renkte bitkiler elde edilmiştir (Fukusaki ve ark., 2004). Tütünde yapılan bir diğer çalışmada, flavonoid biyosentezine katılan kalkon izomeraz (CHI) enzimi RNAi ile baskılanarak petalde flavonoid bileşeninin değişimiyle bitki pigmentasyonu azaltılmıştır (Nishihara ve ark., 2005).

\section{Besin içeriğinin değiştirilmesi}

Bitkiler intiyaç duyduğumuz besinlerin çoğunu karşılarlar. Fakat, temel gıda ürünleri, çoğu besin ögesi yönünden fakir olması nedeniyle beslenme bozukluklarına sebep olabilmektedirler. Bu sebeple, yiyeceklerin besin içeriğinin artırılmasında RNAi teknolojisinden faydalanılmaktadır. Patateste yapılan bir çalışmada, RNAi teknolojisi kullanılarak $\quad \beta$-karoteni zeaksantine dönüştüren $\beta$-karoten hidroksilaz $(\mathrm{BCH})$ gen 
transkriptinin susturulmasıyla $\beta$-karoten içeriği arttırılmıştır (Van Eck ve ark., 2007). Aynı şekilde, Brassica napus bitkisinin besin değerini geliştirmek için, yüksek miktarda erukik asit (\%40) ve düşük miktarda oleik asit (\%20) içeren kültür bitkilerinde, RNAi aracılığıyla, fatty acid elongase1 (BnFAE1) geninin ifadesi baskılandığında, erukik asit içeriği azalmış (\%3) ve oleik asitin içeriği artmıştır (>\%60). Transgenik ve transgenik olmayan bitkilerin karşılıklı çaprazlanmasıyla elde edilen $F_{1}$ tohumlarında da erurik asitte azalma (<\%4) ve oleik asitte artma (\%52) saptanmıştır (Shi ve ark., 2015).

\section{Meyvelerin raf ömrünün uzatılması}

Meyveler, ek besin maddelerinin kaynağı olmaları sebebiyle önemlidirler. Meyvenin, besin değeri, tadı ve raf ömrü gibi özellikleri kaliteyi belirleyici unsurlardır. Bu sebeple meyve olgunlaşmasındaki metabolik sürecin aydınlatılması ile meyve raf ömrünün artırılarak ürün kaybının azaltılması, ticari sebeplerden dolayı oldukça ilgi çekmektedir. Dünyada en çok tüketilen meyvelerin başında gelen domateste, olgunlaşmayı geciktirmek için yapılan bir çalışmada, olgunlaşmada role sahip bir bitki büyüme düzenleyicisi olan etilenin oksidasyonunu katalizleyen

1-Aminosiklopropan-1carboksilat (ACC) oksidaz geni RNAi ile baskılanmıştır. Domates ACC oksidazın çift zincirli RNA'sının (dsRNA), karnabahar mozaik virüs (CMV) $35 \mathrm{~S}$ promotoru kullanılarak $A$. tumefaciens aracılığıyla Hezuo 906 adlı domates çeşidine başarılı bir şekilde transforme edilmesi sonucu çok az miktarda etilen üreten, 120 günden fazla raf ömrüne sahip transgenik domates elde edilmiştir (Xiong ve ark., 2005). Muzda (Musa acuminata) ise, iki $\mathrm{E}$ sınıfı (SEPALLATA3 [SEP3]) MADS box genleri olan ve domatesteki RIN-MADS olgunlaşma genlerine homolog olan MaMADS1 ve MaMADS2 genlerinin işlevsel olarak karakterize edildiği bir çalışmada, bu iki genin RNAi ile susturulduğu transgenik muzlarda olgunlaşma geciktirilmiştir ve muz olgunlaşma sürecinin, domatesin aksine, en az iki SEPALLATA MADS box gen üyesine gereksinim duyduğu belirtilmiştir (Elitzur ve ark., 2016).

\section{Toksik bileşiklerin uzaklaştırılması}

Bitkilerin çok çeşitli toksinleri çevreden alarak bünyelerinde barındırabildikleri veya ilgili genlerin katılımıyla toksik olmayan bileşenlere dönüştürerek fitoremediasyon işlemini gerçekleştirdikleri bilinmektedir. Toksinler, istenen ürünlerin saflaştırılmasını engellerler ve bu istenmeyen bileşenlerin bitkiden uzaklaştırılması oldukça pahalıya mal olmaktadır. Bu sebeple RNAi kullanılarak toksinden arınmış transgenik bitki eldesi oldukça avantajlı olabilir. Bu doğrultuda, önemli bir endüstri bitkisi olan pamuk tohumunda ve yağında bulunan terpenoid gossipol toksini, RNAi ile gossipol biyosentez yolağındaki kadinen sentaz geni, tohuma özgü promotor kullanılarak yalnızca tohumda baskılanmış, böceklere karşı savunmayı etkilememek için yapraklar normal seviyede terpenoid üretmeye devam ettirilmiştir (Sunilkumar ve ark., 2006). Pirinç tohumunda yapılan bir çalışmada da, kadmiyum (Cd) birikimini azaltmak için, ağır metal birikiminde ve direncinde önemli rolü olan fitokelatin sentaz geni (OsPCS1), RNAi ile baskılanmıştır. Bunun için, PCS gen parçasının hairpin yapısı, mısır tohumuna özgü promotor olan ZMM1'in kontrolündeki pRNAi-OsPCS1 içinde dizayn edilmiş ve $A$. tumefaciens aracılığıyla pirince aktarılmıştır (Li ve ark., 2007).

Bağırsaklardaki villus yapıların bozulmasına neden olarak besinin emilimini 
engelleyen tedavisiz bir sindirim sistemi hastalığı olan çölyak hastalığı, buğday, arpa, yulaf ve çavdarda bulunan gluten proteinleri tarafından tetiklenmektedir. Buğday hatlarında yapılan bir çalışmada, glutenin bileşeni olan gliadin proteinlerinin ifadesi RNAi ile baskılanarak toksik olmayan tahıl elde edilmiştir (Gil-Humanes ve ark., 2014).

Son yıllarda yapılan çalışmalar, bitkilerin ağır metal toleransında miRNA genlerin rolünü göstermiştir. Örneğin, pirinçte, $\mathrm{Cd}$ stresine bağlı olarak, miR390'nın ifadesinin azaldığı, hedef geni olan OsSRK geninin ifadesinin ise arttığı gözlenmiştir (Ding ve ark., 2016). miR390'nın ekspresyonunun arttırıldığı transgenik pirinçte ise aksi bir şekilde OsSRK ifadesinin azaldığı, $\mathrm{Cd}$ toleransının yabani türe kıyasla azaldığı ve Cd'nin bitkide yığılımının arttığı belirtilmiştir. Jung ve ark. (2015), Arabidopsis thaliana'da yaptıkları bir araştırmada, aralarında miR157, miR160, miR165, miR168, miR171, miR319, miR397 ve miR403 gibi miRNA ailelerin olduğu 18 miRNA'nın, sezyum (Cs) metal toksinine yanıt olarak ifadelerinin değiştiği gözlenmiştir. Ayrıca, Cs toksininin pri-miRNA işlenmesi ve AGO1 aracılı gen susturulması mekanizmalarını da tahrip ettiği saptanmıştır. Medicago truncatula'da yapılan bir diğer çalışmada ise yeni nesil dizileme tekniği ile aluminyum (Al) stresine duyarlı 321 bilinen ve 21 yeni miRNA tanımlanmıştır (Chen ve ark., 2012).

\section{Tohumsuz bitki üretimi}

Tohum ve meyve gelişimi içsel sinyaller ve çevresel etkenler ile kontrol edilir. Bozulmayı hızlandırıcı maddelerin tohumdan üretilmesi sebebiyle meyvelerin tohumsuz olması, meyve kalitesini ve raf ömrünü artırması sebebiyle tercih edilmektedir (Pandolfini, 2009). Tohumsuz meyve üretmek için gerekli yöntemlerden biri tozlaşma ve döllenme olmaksızın meyve gelişimidir. Meyve olgunlaşmasının başlaması fitohormonlarla kontrol edilir ve döllenmeden bağımsız gerçekleşebilir. Tozlaşmadan önce çiçekleri oksin, giberellin ve sitokininlerle ya da bu hormonların karışımı ile muamele etmenin döllenme olmaksızın meyve gelişimini sağladığı, domates ve patlıcanda yapılan çalışmalarda gösterilmiştir.

Domateste (Solanum lycopersicum), oksin ve giberellin yanıtlarını düzenleyici olduğu belirtilen SIARF7 (Solanum lycopersicum Auxin Response Factor) transkript seviyesi RNAi tekniği ile susturularak partenokarpik meyve elde edilmiştir (de Jong ve ark., 2009). Mısırda yapılan diğer bir çalışmada ise, miR159, miR164, miR166, miR171, miR390, miR399, ve miR529 ailelerinin tane embriyogenezinde önemli işlevleri olduğu gösterilmiştir (Li ve ark., 2016).

Sonuç olarak, her yıl hızla artan dünya nüfusunun ihtiyacını karşılayabilmek için, yiyecek, yem ve endüstri gibi pekçok alanda faydalandığımız bitkilerden en yüksek oranda verim elde edebilmek için etkili yöntemler geliştirmek zorundayız. Bu bağlamda, bu derlemede sunulan örnekler doğrultusunda, miRNA tabanlı RNAi teknolojisinin bitki biyoteknolojisinin amaçladığı birçok alanda etkili bir araç olduğu ve olacağı görülmektedir.

\section{Kaynaklar}

Allen, E., Xie, Z., Gustafson, A. M., Carrington, J. C., 2005. MicroRNA-directed phasing during trans-acting siRNA biogenesis in plants. Cell, 121(2): 207-221.

Chavez Montes, R. A., de Fatima Rosas-Cardenas, F., De Paoli, E., Accerbi, M., Rymarquis, L. A., Mahalingam, G., Marsch-Martinez, N., Meyers, B. C., Green, P. J., de Folter, S., 2014. Sample sequencing of vascular plants demonstrates widespread conservation and divergence of 
microRNAs. Nature Communications, 5(1): 3722.

Chen, L., Wang, T., Zhao, M., Tian, Q., Zhang, W. H., 2012. Identification of aluminumresponsive microRNAs in Medicago truncatula by genome-wide highthroughput sequencing. Planta, 235(2): 375-386.

Cheng, H. Y., Wang, Y., Tao, X., Fan, Y. F., Dai, Y., Yang, H., Ma, X. R., 2016. Genomic profiling of exogenous abscisic acidresponsive microRNAs in tomato (Solanum lycopersicum). BMC Genomics, 17(1): 423.

de Jong, M., Wolters-Arts, M., Feron, R., Mariani, C., Vriezen, W. H., 2009. The Solanum lycopersicum auxin response factor 7 (SIARF7) regulates auxin signaling during tomato fruit set and development. The Plant Journal, 57(1): 160-170.

Ding, Y., Ye, Y., Jiang, Z., Wang, Y., Zhu, C., 2016. MicroRNA390 is involved in cadmium tolerance and accumulation in rice. Front Plant Sci, 7(1): 235.

Elitzur, T., Yakir, E., Quansah, L., Zhangjun, F., Vrebalov, J., Khayat, E., Giovannoni, J. J., Friedman, H., 2016. Banana MaMADS transcription factors are necessary for fruit ripening and molecular tools to promote shelf-life and food security. Plant Physiology, 171(1): 380-391.

Fahlgren, N., Jogdeo, S., Kasschau, K. D., Sullivan, C. M., Chapman, E. J., Laubinger, S., Smith, L. M., Dasenko, M., Givan, S. A., Weigel, D., Carrington,J. C., 2010. MicroRNA gene evolution in Arabidopsis lyrata and Arabidopsis thaliana. Plant Cell, 22(4): 1074-1089.

Fan, C., Hao, Z., Yan, J., Li, G., 2015. Genome-wide identification and functional analysis of lincRNAs acting as miRNA targets or decoys in maize. BMC Genomics, 16(1): 793.

Field, S., Thompson, B., 2016. Analysis of the Maize dicer-like1 Mutant, fuzzy tassel, Implicates MicroRNAs in Anther Maturation and Dehiscence. PLoS One, 11(1): e0146534.

Fukusaki, E., Kawasaki, K., Kajiyama, S., An, C. I., Suzuki, K., Tanaka, Y., Kobayashi, A., 2004. Flower color modulations of Torenia hybrida by downregulation of chalcone synthase genes with RNA interference. J Biotechnol, 111(3): 229-240.

Gil-Humanes, J., Piston, F., Barro, F., Rosell, C. M., 2014. The shutdown of celiac disease- related gliadin epitopes in bread wheat by RNAi provides flours with increased stability and better tolerance to overmixing. PLoS One, 9(3): e91931.

Gilissen, L. J., Bolhaar, S. T., Matos, C. I., Rouwendal, G. J., Boone, M. J., Krens, F. A., Zuidmeer, L., Van Leeuwen, A., Akkerdaas, J., Hoffmann-Sommergruber, K., Knulst, A. C., Bosch, D., Van de Weg, W. E., Van Ree, R., 2005. Silencing the major apple allergen $\mathrm{Mal} d 1$ by using the RNA interference approach. J Allergy Clin Immunol, 115(2): 364-369.

Gronquist, M., Bezzerides, A., Attygalle, A., Meinwald, J., Eisner, M., Eisner, T., 2001. Attractive and defensive functions of the ultraviolet pigments of a flower (Hypericum calycinum). Proc Natl Acad Sci U S A, 98(24): 13745-13750.

Guo, H. S., Xie, Q., Fei, J. F., Chua, N. H., 2005. MicroRNA directs mRNA cleavage of the transcription factor NAC1 to downregulate auxin signals for Arabidopsis lateral root development. Plant Cell, 17(5): 1376-1386.

Gutierrez , L., Bussell, J. D., Pacurar, D. I., Schwambach, J., Pacurar, M., Bellini, C., 2009. Phenotypic plasticity of adventitious rooting in Arabidopsis is controlled by complex regulation of AUXIN RESPONSE FACTOR transcripts and microRNA abundance. Plant Cell, 21(10): 3119-3132.

Han, J. Y., Kwon, Y. S., Yang, D. C., Jung, Y. R., Choi, Y. E., 2006. Expression and RNA interference-induced silencing of the dammarenediol synthase gene in Panax ginseng. Plant Cell Physiol, 47(12): 16531662.

Herman, E. M., Helm, R. M., Jung, R., Kinney, A. J., 2003. Genetic modification removes an immunodominant allergen from soybean. Plant Physiol, 132(1):36-43.

Jalali, S., Bhartiya, D., Lalwani, M. K., Sivasubbu, S., Scaria, V., 2013. Systematic transcriptome wide analysis of IncRNAmiRNA interactions. PLoS One, 8(2): e53823.

Jiao, Y., Wang, Y., Xsu, D., Wang, J., Yan, M., Liu, G., Dong, G., Zeng, Z., Lu, Z., Zhu, X., Qian, Q., Li, J., 2010. Regulation of OsSPL14 by OsmiR156 defines ideal plant architecture in rice. Nature Genetics, 42(6),541-544.

Jones-Rhoades, M. W., 2012. Conservation and divergence in plant microRNAs. Plant Mol Biol, 80(1): 3-16. 
Jung, I. L., Ryu, M., Cho, S. K., Shah, P., Lee, J. H., Bae, H., Kim, I. G., Yang, S. W., 2015. Cesium toxicity alters microRNA processing and AGO1 Expressions in Arabidopsis thaliana. PLoS One, 10(5): e0125514.

Kempe, K., Higashi, Y., Frick, S., Sabarna, K., Kutchan, T. M., 2009. RNAi suppression of the morphine biosynthetic gene salAT and evidence of association of pathway enzymes. Phytochemistry, 70(5): 579-589.

Kozomara, A., Griffiths-Jones, S., 2014. miRBase: annotating high confidence microRNAs using deep sequencing data. Nucleic Acids Research, 42:D68-D73

Lauter, N., Kampani, A., Carlson, S., Goebel, M., Moose, S. P., 2005. MicroRNA172 downregulates glossy15 to promote vegetative phase change in maize. Proceedings of the National Academy of Sciences of the United States of America, 102(26): 94129417.

Le, L. Q., Mahler, V., Lorenz, Y., Scheurer, S., Biemelt, S., Vieths, S., Sonnewald, U., 2006. Reduced allergenicity of tomato fruits harvested from Lyc e 1-silenced transgenic tomato plants. J Allergy Clin Immunol, 118(5): 1176-1183.

Lee, R.C., Feinbaum, R.L., Ambros, V., 1993. The C. elegans heterochronic gene lin-4 encodes small RNAs with antisense complementarity to lin-14. Cell, 75(5): 843-854.

Li, D., Liu, Z., Gao, L., Wang, L., Gao, M., Jiao, Z., Qiao, H., Yang, J., Chen, M., Yao, L., Liu, R., Kan, Y., 2016. Genome-Wide Identification and Characterization of microRNAs in Developing Grains of Zea mays L. PLoS One, 11(4): e0153168.

Li, J. C., Guo, J. B., Xu, W. Z., Ma, M., 2007. RNA Interference-mediated Silencing of Phytochelatin Synthase Gene Reduce Cadmium Accumulation in Rice Seeds. Journal of Integrative Plant Biology, 49(7): 1032-1037.

Luan, M., Xu, M., Lu, Y., Zhang, L., Fan, Y., Wang, L., 2015. Expression of zma-miR169 miRNAs and their target $Z m N F-Y A$ genes in response to abiotic stress in maize leaves. Gene, 555(2): 178-185.

Nawaz-ul-Rehman, M. S., Mansoor, S., Khan, A. A., Zafar, Y., Briddon, R. W., 2007. RNAimediated male sterility of tobacco by silencing TA29. Mol Biotechnol, 36(2): 159165.
Nie, Z., Ren, Z., Wang, L., Su, S., Wei, X., Zhang, X., Wu, L., Liu, D., Tang, H., Liu, H., Zhang, S., Gao, S., 2016. Genome-wide identification of microRNAs responding to early stages of phosphate deficiency in maize. Physiol Plant, 157(2): 161-174.

Nishihara, M., Nakatsuka, T., Yamamura, S., 2005. Flavonoid components and flower color change in transgenic tobacco plants by suppression of chalcone isomerase gene. FEBS Lett, 579(27): 6074-6078.

Nogueira, F. T., Madi, S., Chitwood, D. H., Juarez, M. T., Timmermans, M. C., 2007.

Two small regulatory RNAs establish opposing fates of a developmental axis. Genes Dev, 21(7): 750-5.

Pandolfini, T., 2009. Seedless fruit production by hormonal regulation of fruit set. Nutrients, 1(2): 168-177.

Poethig, R. S., 2013. Vegetative phase change and shoot maturation in plants. Curr Top Dev Biol, 105: 125-152.

Rogers, K., Chen, X., 2013. Biogenesis, Turnover, and Mode of Action of Plant MicroRNAs. The Plant Cell, 25(7): 2383-2399.

Shen, Y., Zhang, Z., Lin, H., Liu, H., Chen, J., Peng, H., Cao, M., Rong, T., Pan, G., 2011. Cytoplasmic male sterility-regulated novel microRNAs from maize. Funct Integr Genomics, 11(1): 179-191.

Shi, J., Lang, C., Wu, X., Liu, R., Zheng, T., Zhang, D., Chen, J., Wu, G., 2015. RNAi knockdown of fatty acid elongase1 alters fatty acid composition in Brassica napus. Biochem Biophys Res Commun, 466(3): 518-522.

Shriram , V., Kumar, V., Devarumath, R. M., Khare, T. S., Wani, S. H., 2016. MicroRNAs as potential targets for abiotic stress tolerance in Plants. Front. Plant Sci, 7(1): 817.

Sun, G., 2012. MicroRNAs and their diverse functions in plants. Plant Mol Biol, 80(1): 17-36.

Sunilkumar, G., Campbell, L. M., Puckhaber, L., Stipanovic, R. D., Rathore, K. S., 2006. Engineering cottonseed for use in human nutrition by tissue-specific reduction of toxic gossypol. Proc Natl Acad Sci U S A, 103(48): 18054-18059.

Van Eck, J., Conlin, B., Garvin, D. F., Mason, H., Navarre, D. A., Brown, C. R., 2007. Enhancing beta-carotene content in potato by rnai-mediated silencing of the beta-carotene hydroxylase gene. American 
Journal of Potato Research, 84(4): 331342.

Waterhouse, P. M., Graham, M. W., Wang, M. B., 1998. Virus resistance and gene silencing in plants can be induced by simultaneous expression of sense and antisense RNA. Proc Natl Acad Sci U S A, 95(23): 1395913964.

Wu, X., Ding, D., Shi, C., Xue, Y., Zhang, Z., Tang, G., Tang, J., 2016. MicroRNA-dependent gene regulatory networks in maize leaf senescence. BMC Plant Biol, 16(1): 73.

Wu, F., Shu, J., Jin, W., 2014. Identification and validation of miRNAs associated with the resistance of maize (Zea mays L.) to Exserohilum turcicum. PLoS One, 9(1): e87251.

Xiong, A. S., Yao, Q. H., Peng, R. H., Li, X., Han, P. L., Fan, H. Q., 2005. Different effects on ACC oxidase gene silencing triggered by RNA interference in transgenic tomato. Plant Cell Rep, 23(9): 639-646.

Xu, Z., Zhong, S., Li, X., Li, W., Rothstein, S. J., Zhang, S., Bi, Y., Xie, C., 2011. Genomewide identification of microRNAs in response to low nitrate availability in maize leaves and roots. PLoS One, 6(11): e28009.

Yang , C., Li, D., Mao, D., Liu, X., Ji, C., Li, X., Zhao, X., Cheng, Z., Chen, C., Zhu, L., 2013. Overexpression of microRNA319 impacts leaf morphogenesis and leads to enhanced cold tolerance in rice (Oryza sativa L.). Plant Cell Environ, 36(12): 2207-2218.

Yang , J. S., Phillips, M. D., Betel, D., Mu, P., Ventura, A., Siepel, A. C., Chen, K. C., Lai, E. C., 2011. Widespread regulatory activity of vertebrate microRNA* species. Rna, 17(2): 312-326.

Zhai, L., Liu, Z., Zou, X., Jiang, Y., Qiu, F., Zheng Y. Zhang, Z., 2013. Genome-wide identification and analysis of microRNA responding to long-term waterlogging in crown roots of maize seedlings. Physiol Plant 147(2): 181-193.

Zhang, C., Ding, Z.,Wu, K., Yang, L., Li, Y., Yang, Z., Shi, S., Liu, X., Zhao, S., Yang, Z., Wang, Y., Zheng, L., Wei, J., Du, Z., Zhang, A., Miao, H., Li, Y., Wu, Z., Wu, J., 2016. Suppression of Jasmonic Acid-mediated Defense by Viral-inducible MicroRNA319 Facilitates Virus Infection in Rice. Molecular Plant, 9(9):1302-1314.

Zhang, L., Jing, F., Li, F., Li, M., Wang, Y., Wang, G., Sun, X., Tang, K., 2009. Development of transgenic Artemisia annua (Chinese wormwood) plants with an enhanced content of artemisinin, an effective antimalarial drug, by hairpin-RNA-mediated gene silencing. Biotechnol Appl Biochem, 52(3): 199-207.

Zhou, Y., Xu, Z., Duan, C., Chen, Y., Meng, Q., Wu, J., Hao, Z., Wang, Z., Li, M., Yong, H., Zhang, D., Zhang, S., Weng, J., Li, X., 2016. Dual transcriptome analysis reveals insights into the response to Rice blackstreaked dwarf virus in maize. J Exp Bot, 67(15): 4593-4609. 